\title{
Enhanced Effect of Nitrogen and Phosphorus on Growth and Yield of Capsicum: A Review
}

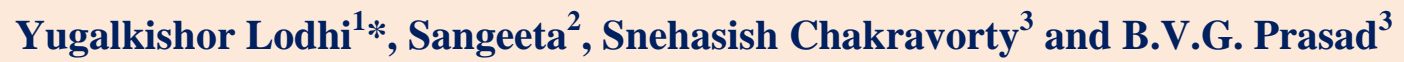 \\ ${ }^{1}$ Department of Vegetable Science, College of Agriculture, Indira Gandhi Krishi \\ Viswavidyalaya, Krishak Nagar, Raipur-492012 (C.G.), India \\ ${ }^{2}$ Department of Fruit Science, College of Agriculture, \\ Indira Gandhi Krishi Viswavidyalaya, Krishak Nagar, Raipur-492012 (C.G.), India \\ ${ }^{3}$ Department of Vegetable Science, Visva-Bharati, Sriniketan (West Bengal), India \\ *Corresponding author
}

Keywords

Nitrogen,

Phosphorus,

Growth parameters,

Yield components,

Capsicum etc

Article Info

Accepted:

26 October 2019

Available Online:

10 November 2019
This review article is based on complete articles and abstracts. The nutrition status of any plants plays a vital role in determining its growth, yield and quality of fruits. An optimal fertilization is contributive in obtaining high yield of good quality and high biological value. Both macro and micronutrients are well known to ameliorate plant growth, yield and quality. Application of nutrients especially macronutrients like nitrogen, phosphorus and potassium etc. is well known to enhance the crop growth and development for optimum yield and to improve quality of produce. It is evident from literature, that nitrogen and phosphorus affect growth, yield and quality of fruits and vegetables. The available literature on effect of nitrogen and phosphorus application on growth parameters, yield components and quality of capsicum and other fruits or vegetable crops are reviewed and presented below.

\section{Introduction}

Capsicum is one of the most popular vegetable crops, also known as Bell pepper, Sweet pepper or Green pepper or Shimla Mirch. It belongs to family Solanaceae and is native to Mexico with secondary centre of origin at Guatemala and Bulgaria (Safford, 1926).
Sweet pepper is relatively non-pungent or less pungent with thick flesh. Chilli is the third important crop of family Solanaceae after tomato and potato (Naz, 2006). It is cultivated throughout the world, mostly in temperate regions of Central and South America and European countries, tropical and subtropical regions of Asian continent mainly in India and 
China. India contributes one fourth of world production of Bell pepper with an average annual production of 327 thousand tons from an area of 46,000 hectare with a productivity of $7108.70 \mathrm{~kg}$ per hectare from open as well as protected cultivation (Anonymous, 2017). It is extensively cultivated in hills of Himachal Pradesh, Uttar Pradesh, Jammu and Kashmir and Nilgiri hills during summer months. As an autumn crop, it extends up to winter months in Karnataka, Maharashtra, Tamil Nadu, Andhra Pradesh, Bihar, West Bengal and Madhya Pradesh (NHB, 2016-17).

Capsicum is consumed as cooked vegetable or as raw salad. Juroszek and Tsai (2009) reported that sweet pepper fruits are good sources of many essential nutrients, including vitamins $\mathrm{A}, \mathrm{C}$, and $\mathrm{E}$, carotenoids, minerals (e.g., calcium and iron), and other secondary plant compounds. It is highly nutritious with abundant source of vitamins $\mathrm{A}$ and $\mathrm{C}$, minerals like phosphorus, potassium, calcium and magnesium. A $100 \mathrm{~g}$ fresh weight of bell pepper contains vitamin A (3131 IU), vitamin C $(283 \mathrm{mg})$, protein $(1.29 \mathrm{mg})$, calcium (13.4 $\mathrm{mg}$ ), magnesium (14.9 mg), phosphorus (28.3 $\mathrm{mg}$ ) and potassium (263.0 $\mathrm{mg}$ ) (Arya, P.S., 1999 and IIHR, 2000).

The mineral nutrients, $\mathrm{N}, \mathrm{P}$ and $\mathrm{K}$ are known to affect growth and yield of the capsicums. Stroehlein and Oebker (1979) reported that N applications to chili peppers showed a significant increase on plant growth characteristics, color and nutrient content of leaves and yield. Crucial role of nitrogen for being main constituent of all amino acids in proteins and lipids, the structural compounds of cells and chloroplast made it the most essential macronutrient for good plant establishment and expected growth (Uddin and Khalequzzaman, 2003). Therefore, its deficiency shows negative impact on growth and development of plants which is ultimately reduces plant yield. Reports of various investigations indicated its significant role in stimulating the plants for uptake of potassium and phosphorus through its synergistic effect (Qawasmi et al., 1999). Bell pepper requires heavy nitrogen application for higher yield as it imparts good vegetative growth necessary for good development of fruit.

Phosphorus is also one of the important macronutrients play a vital role in crop growth as it is involved in several key plant cellular activities like energy transfer, photosynthesis, transformation of sugars and starches and transfer of genetic characteristics from one generation to the next. It also promotes root proliferation that increases root volume and improves soil nutrient exploration. Phosphorus shortage restricted the plant growth and remains immature (Hossain, 1990). The effect of phosphorus on the formation and translocation of carbohydrates, roots development, nodulation, growth and other agronomic characters are well recognized. Phosphorus induces earliness in flowering and fruiting including seed formation (Buckman and Brady, 1980). Again, secondary mechanism of interference was the absorption of phosphorus from the soil through luxury consumption, increasing the tissue content without enhancing smooth biomass accumulation (Santos et al., 2004). To attain considerable production and quality yield for chilli it is necessary to proper management including ensuring the availability of essential nutrient components in proper doses.

The available literature on the effect of nutrient application on growth, yield components and quality of bell pepper and other fruits or vegetables are reviewed and presented below:

Lodhi et al., (2019) reported that the fruit yield of bell pepper was significantly influenced by nutrients and mulching. The highest fruit yield per plant (739.31g), fruit 
yield per plot $(12.67 \mathrm{~kg})$ and fruit yield per hectare $\left(21.12 \mathrm{t} \mathrm{ha}^{-1}\right)$ were recorded in treatment $\mathrm{T}_{6}$ with $200 \mathrm{~kg} \mathrm{~N}^{-1}+80 \mathrm{~kg} \mathrm{P}_{2} \mathrm{O}_{5}$ ha ${ }^{-1}+$ Paddy straw mulch @ $7 \mathrm{t} / \mathrm{ha}^{-1}$.

Lodhi et al., (2019) conducted a field experiment and observed that the fruiting and fruit characteristics of bell pepper significantly influenced by nutrients and mulching. Highest number of fruits per plant (9.95), highest fruit weight $(69.18 \mathrm{~g})$, maximum fruit length $(9.95 \mathrm{~cm})$, diameter $(7.37 \mathrm{~cm})$ and volume $\left(97.07 \mathrm{~cm}^{3}\right)$ were observed in the treatment $\mathrm{T}_{6}$ with $200 \mathrm{~kg} \mathrm{~N} \mathrm{ha}^{-1}+80 \mathrm{~kg} \mathrm{P}_{2} \mathrm{O}_{5} \mathrm{ha}^{-1}+$ Paddy straw mulch@7 t/ha ${ }^{-1}$. Control condition indicated significantly lowest result than all other treatments.

Fruit quality of bell pepper was significantly influenced by different levels of nitrogen and phosphorus. The bio-chemical parameters viz. TSS, chlorophyll content and Vitamin-C increased with increasing rate of nutrients. Highest total soluble solids (7.410Bx), chlorophyll content (63.28 SPAD) and Vitamin-C (197.64 mg/100g) were observed in treatment $\mathrm{T}_{8}$ with $200 \mathrm{~kg} \mathrm{~N}^{-1}+120 \mathrm{~kg}$ $\mathrm{ha}^{-1} \mathrm{P}_{2} \mathrm{O}_{5}+$ Paddy straw mulch @ $7 \mathrm{t} \mathrm{ha}^{-1}$. Control condition indicated significantly lowest result than all other treatment (Lodhi et al., 2019).

Islam et al., (2018) investigated the influence of nitrogen and phosphorus on growth and yield of chilli and found that growth and yield contributing parameters significantly influenced by different doses of nitrogen and phosphorus fertilizers. Most of the growth parameters increased with increasing level nitrogen and phosphorus between 120 to 140 $\mathrm{kg} \mathrm{N} \mathrm{ha}^{-1}$ and 45 to $60 \mathrm{~kg} \mathrm{P}_{2} \mathrm{O}_{5} \mathrm{ha}^{-1}$. Based on the investigation results, it can be suggested that the combined use of $140 \mathrm{~kg} \mathrm{~N} \mathrm{ha}^{-1}$ with $60 \mathrm{~kg} \mathrm{P}_{2} \mathrm{O}_{5}$ ha $^{-1}$ increased plant growth and fruit yield of chilli. A field experiment was conducted by Dubey et al., (2017) and observed that the treatment combination of N.P.K. (175:55:45 kg/ha) was superior overall other treatments in relation to growth parameters but low in production and quality. N.P.K. (155:55:45 kg. /ha) was found superior in terms of yield and N.P.K. (155:55:55 kg/ha) was superior in relation to quality (fruit length, fruit diameter, shelf life, TSS) of capsicum. Thus, application of optimum doses of NPK was found highly beneficial for plant growth, yield and quality of capsicum.

A greenhouse experiment was conducted by Hussein Hussein Alhrout, (2017) and evaluated plant height $(\mathrm{cm})$, leaves number per plant, number of days to $50 \%$ flowering, fruit number per plant, fruit length, yield of fruit per plant $(\mathrm{kg})$, and yield of fruit per hectare (t/ha). He concluded that the NPK treatment gives highest plant height $(\mathrm{cm})$, leaves number per plant, fruits number per plant, yield of fruits per plant $(\mathrm{kg})$, and yield of fruits per hectare $(\mathrm{t} / \mathrm{ha})$.

A field investigation was carried out by Lodhi et al., (2017) and observed that growth parameters were significantly influenced by different nutrients levels. The highest plant height $(62.87 \mathrm{~cm})$, stem diameter $(12.18 \mathrm{~mm})$, highest primary and secondary branches $(2.84$ and 5.94) were recorded in treatment $\mathrm{T}_{6}$ with $200 \mathrm{~kg} \mathrm{~N} / \mathrm{ha}+80 \mathrm{~kg} \mathrm{P}_{2} \mathrm{O}_{5} / \mathrm{ha}+$ paddy straw mulch @ 7t/ha. Appearance of early flowering, 50\% flowering and days to first harvest (51.10 days, 84.02 days and 101.00 days respectively) were observed in treatment $\mathrm{T}_{4}$ with $150 \mathrm{~kg} \mathrm{~N} / \mathrm{ha}+120 \mathrm{~kg} / \mathrm{ha} \mathrm{P}_{2} \mathrm{O}_{5}+$ paddy straw mulch@ 7 t/ha.

Mebratu et al., (2014) found that nitrogen had significant effect on yield and quality components of hot pepper (Capsicum annum L.). Nitrogen at $100 \mathrm{~kg} \mathrm{ha}^{-1}$ resulted in the highest total dried pod yield $\left(3.1 \mathrm{t} \mathrm{ha}^{-1}\right)$, marketable yield $\left(2.7 \mathrm{t} \mathrm{ha}^{-1}\right)$ pod length $(10.6$ $\mathrm{cm})$ and pod width $(3.4 \mathrm{~cm})$.Application of 
nitrogen at the rate of $100 \mathrm{~kg} \mathrm{ha}^{-1}$ also improved the physical quality attributes of hot pepper.

The influence of nitrogen and potassium levels on chilli (Capsicum annuum L.) was evaluated by Khan et al., (2014). Nitrogen levels showed significant effect on all growth and yield parameters. The maximum plant height (68.3 $\mathrm{cm})$, number of leaves plant ${ }^{-1}$ (294), number of branches plant ${ }^{-1}$ (18.3), stem thickness $(2.43 \mathrm{~cm})$, fruits plant ${ }^{-1}$ (59.4), fruit length $(6.83 \mathrm{~cm})$, seeds fruit ${ }^{-1}(152)$ and yield $(8.803$ tons $\left.\mathrm{ha}^{-1}\right)$ were recorded with Nitrogen application at the rate of $180 \mathrm{~kg} \mathrm{ha}^{-1}$.

Roy et al., (2011) observed the effect of nitrogen and phosphorus on the fruit characteristics and yield attributing parameters of Capsicum. Length, breadth of fruit and number of fruits per plant were increased significantly with increasing nitrogen doses up to $150 \mathrm{~kg} \mathrm{~N} \mathrm{ha}^{-1}$ and average weight of fruit content increased significantly up to $200 \mathrm{~kg} \mathrm{~N}$ $\mathrm{ha}^{-1}$. On the other hand, average weight of fruit and yield increased significantly with increasing levels of $\mathrm{P}$ up to the treatment 30 $\mathrm{kg} \mathrm{P} \mathrm{ha}{ }^{-1}$, whereas length of fruit and number fruits per plant was increased significantly up to the $60 \mathrm{~kg} \mathrm{P} \mathrm{ha}^{-1}$. Considering the combined effect of nitrogen and phosphorus, the maximum significant length of Capsicum, breadth of Capsicum, number of fruits per plant and, average weight of fruit as well as yield were found in the treatment combination of $200 \mathrm{~kg} \mathrm{~N}$ and $30 \mathrm{~kg} \mathrm{P} \mathrm{ha}^{-1}$.

Roy et al., (2011) Conducted experiment on Nitrogen and Phosphorus Efficiency on the Fruit Size and Yield of Capsicum and identified the highest number of fruits per plant (8.61) was found with $200 \mathrm{~kg} \mathrm{~N} \mathrm{ha}^{-1}$ and the lowest number of fruits per plant (4.32) was found in control treatment. Malik et al., (2011) studied on the effect of inorganic fertilizers on Growth, yield and fruit quality of sweet pepper hybrid SH-SP-5 (Capsicum annuum L.). Application of $200 \mathrm{~kg} \mathrm{~N} \mathrm{ha}{ }^{-1}$, $120 \mathrm{~kg} \quad \mathrm{P}_{2} \mathrm{O}_{5} \quad \mathrm{ha}^{-1}, 60 \mathrm{~kg} \quad \mathrm{~K}_{2} \mathrm{O}$ ha ${ }^{-1}$ to capsicum crop recorded maximum plant height $(55.65 \mathrm{~cm})$, number of branches $(6.61)$, plant spread $(44.50 \mathrm{~cm})$, fruit length $(8.30$ $\mathrm{cm})$, fruit diameter $(8.00 \mathrm{~cm})$ and the highest fruit quality in terms of vitamin-C (243.34 $\mathrm{mg} / 100 \mathrm{~g})$, total chlorophyll content (732.66 $\mathrm{mg} / 100 \mathrm{~g})$, dry matter content $(9.93 \mathrm{~g} / 100 \mathrm{~g})$.

Khan et al., (2010) studied the effect of nitrogen and phosphorus on the growth and yield of capsicum. The results revealed that plant height at final harvest and number of branches at first and final harvest increased significantly up to $200 \mathrm{~kg} \mathrm{~N} \mathrm{ha}^{-1}$ and, whereas plant height and number of branches at final harvest and number fruits per plant enhanced significantly up to $60 \mathrm{~kg} \mathrm{P}_{2} \mathrm{O}_{5} \mathrm{ha}^{-1}$.

Kacha et al., (2008) reported the effect of different nitrogen level on Capsicum annuum cv. S-49). The application of nitrogen at 150 $\mathrm{kg} / \mathrm{ha}$ significantly improved the yield attributes and green fruit yield compared to the lower level $(100 \mathrm{~kg} / \mathrm{ha})$, but was on a par with the higher levels (200 and $250 \mathrm{~kg} / \mathrm{ha}$ ). Nitrogen at $250 \mathrm{~kg} / \mathrm{ha}$ recorded the highest values of nitrogen, phosphorus and potassium content and uptake, and available nitrogen status after harvesting; this treatment was superior to lower levels of nitrogen except 200 $\mathrm{kg} / \mathrm{ha}$. However, the capsaicin content was reduced as the nitrogen level increased.

Singegol et al., (2007) studied the effect of different level of nitrogen fertilizer and phosphorus on growth and yield of Capsicum annuum cv. Pusa Jwala. The results revealed that among nitrogen levels studied, $200 \mathrm{~kg}$ N/ha was significantly better with respect to growth characters like plant height, plant spread, number of primary and secondary branches per plant as well as yield attributing characters like number of fruits per plant and 
average fruit weight. Similar was the response of most of characters to higher phosphorus (75 $\mathrm{kg} / \mathrm{ha}$ ) resulting in higher yield.

Chaudhary et al., (2007) reported that the effects of different nitrogen rates on the growth and yield of Capsicum annuum var. grossum and observed that maximum fruit yield was obtained with $\mathrm{N}$ at $250 \mathrm{~kg} / \mathrm{ha}$, while $\mathrm{P}$ application increased yield by increasing fruit number and fruit yield/plant up to 150 $\mathrm{kg} / \mathrm{ha}$.

Jan et al., (2006) studied the effect of optimum dose of fertilizer and plant spacing on growth and yield of sweet peppers (Capsicum annuum). The greatest plant height $(29.13 \mathrm{~cm})$, number of fruits per plant (15.36), fruit weight $(67.05 \mathrm{~g})$, yield per plant $(1040 \mathrm{~g})$ and yield $\mathrm{ha}^{-1}(43.19 \mathrm{t})$ were recorded with the application of 125:90:70 kg N:P $\mathrm{O}_{5}: \mathrm{K}_{2} \mathrm{Oha}^{-1}$. The maximum plant height $(28.86 \mathrm{~cm})$ and yield ha ${ }^{-1}(45.39 \mathrm{t})$ were recorded at $60 \times 45 \mathrm{~cm}$ spacing. Better performance regarding growth and yield were observed when plants were supplied with 125:90:70 kg N: P: K/ha and spaced at $60 \times 45 \mathrm{~cm}$.

Singh and Jain (2004) the Experiments were conducted to determine the balanced amount of nitrogen, phosphorus and potassium for the higher yield and economics of chilli cv. Pant $\mathrm{C}-1$. The highest fruit yield was recorded with $120 \mathrm{~kg} \mathrm{~N} / \mathrm{ha}+60 \mathrm{~kg} \mathrm{P} / \mathrm{ha}$ with highest gross income (Rs. 46 350), net profit (Rs. 26 150/ha) and cost: benefit ratio (1:2.30).

Sarma et al., (2004) An experiment was conducted during 2000-03 in Gossaigaon, Assam, India to determine the optimum level of NPK for Capsicum annuum. Plant height $(27.25 \mathrm{~cm})$, fruit number per plant (64.33), fruit weight $(3.33 \mathrm{~g})$ and yield $(27.99 \mathrm{q} / \mathrm{ha})$ of Capsicum annuum increased significantly with 200:75:75 kg NPK/ha. The capsaicin contents of green and red ripe fruits were highest at
90:45:45 and 120:60:60 kg NPK/ha. The capsaicin content decreased with further increase in NPK level. The maximum return per rupee invested (3.92) was obtained at 90:45:45 kg NPK/ha, followed by 120:60:60 $\mathrm{kg} \mathrm{NPK/ha} \mathrm{(3.86).}$

Ramakrishna and Palled (2003) studied the effect of plant geometry and fertilizer levels on growth and yield of chilli (cv. Vietnam-2). A spacing of $60 \mathrm{~cm} \times 45 \mathrm{~cm}$ recorded significantly higher fruit yield. Application of 200:75:75 $\mathrm{kg} \mathrm{N}, \mathrm{P}_{2} \mathrm{O}_{5}$ and $\mathrm{K}_{2} \mathrm{O}$ ha $^{-1}$ with 60 $\mathrm{cm} \times 45 \mathrm{~cm}$ spacing recorded significantly higher net returns (Rs.38759 $\mathrm{ha}^{-1}$ ) and B:C ratio (2.56) over other treatment combinations, except $60 \mathrm{~cm} \mathrm{x} 45 \mathrm{~cm}$ with 125:62.5:62.5 kg $\mathrm{N}, \mathrm{P}_{2} \mathrm{O}_{5}$ and $\mathrm{K}_{2} \mathrm{O}$ ha $^{-1}$.

Faiza et al., (2002) reported that the effects of different nitrogen rates on the growth and yield of sweet pepper [Capsicum] cv. Yellow Wonder and observed increase plant height $(41.60 \mathrm{~cm})$, number of branches (9.13), and yield $\mathrm{ha}^{-1}(30.82 \mathrm{t})$ were recorded with the application of $200 \mathrm{~kg} \mathrm{~N} / \mathrm{ha}^{-1}$. Maximum fruiting (18.20) was observed in $100 \mathrm{~kg} \mathrm{~N}$ $\mathrm{ha}^{-1}$. The results showed that better performance in growth and yield were obtained when plants were supplied with 200 $\mathrm{kg} \mathrm{N} \mathrm{ha}{ }^{-1}$.

Gare et al., (2001) reported that the effect of different spacing and NPK fertilizer application on the yield and yield components of Capsicum annuum cv. Phule sai. The results revealed that plant height $(53.60 \mathrm{~cm})$ and number of fruits per plant (48) were highest under the $45 \times 30 \mathrm{~cm}$ spacing, while plant spread $(44.53 \mathrm{~cm})$ and fruit length $(7.8$ $\mathrm{cm}$ ) was highest under the $60 \times 45 \mathrm{~cm}$ spacing. The different fertilizer treatments, $200 \mathrm{~kg}$ $\mathrm{N} / \mathrm{ha}+50 \mathrm{~kg}$ P/ha recorded the highest values for dry chilli yield (1903 kg/ha), plant height $(57.13 \mathrm{~cm})$, plant spread $(47.13 \mathrm{~cm})$, number of fruits per plant $(51)$, fruit length $(8.1 \mathrm{~cm})$ 
and yield of dry chilli per plant (43.1 g). This fertilizer treatment was on a par with the 200 $\mathrm{kg} \mathrm{N} / \mathrm{ha}+37.5 \mathrm{~kg}$ P/ha treatment.

Diaz et al., (2001) conducted experiment on effect of fertilization programme on the yield of pimento (Capsicum annuum L.). The results revealed that an average of $153.7 \mathrm{~g} /$ fruit were obtained with $160-197 \mathrm{~kg} / \mathrm{ha}$ of nitrogen, 42$72 \mathrm{~kg} / \mathrm{ha}$ of phosphorus and $90-168 \mathrm{~kg} / \mathrm{ha}$ of potassium to the best for pepper production.

Mohanty et al., (2001) An experiment was conducted in Orissa, the response of chilli (Capsicum annuum cv. Utkal Rashmi) to $\mathrm{N}$ at $0,40,80$ and $120 \mathrm{~kg} / \mathrm{ha}$, and $\mathrm{P}$ and $\mathrm{K}$ at 0,30 and $60 \mathrm{~kg} / \mathrm{ha}$. N, P and $\mathrm{K}$ at 120, 60 and $\mathrm{K}$ at $30 \mathrm{~kg} / \mathrm{ha}$, respectively, resulted in the tallest plants and maximum number of fruits. $\mathrm{N}, \mathrm{P}$ and $\mathrm{K}$ at 120,30 and $30 \mathrm{~kg} / \mathrm{ha}$, respectively, resulted in the highest yield.

Muhammadet al., (2001) noticed a different level of $\mathrm{N}$ and $\mathrm{P}$ significantly affected in plant height, number of branches per plant, number of fruits per plant and fruit yield of pepper. The tallest plants $(65.2$ and $64.7 \mathrm{~cm})$, the maximum branches per plant (14.1 and 13.8 branches/plant), and the highest number of fruits per plant (62.6 and 59.2) and fruit yield (9577.726 and $8771.44 \mathrm{~kg} / \mathrm{ha}$ ) were recorded when $\mathrm{N}$ and $\mathrm{P}$ each were applied at rates of $200 \mathrm{~kg} / \mathrm{ha}$, and when $\mathrm{N}$ alone was applied at the rate of $200 \mathrm{~kg} / \mathrm{ha}$, respectively. $\mathrm{N}$ and $\mathrm{P}$ each at the rate of $200 \mathrm{~kg} / \mathrm{ha}$ is recommended for the highest yield of pepper.

Srinivasan et al., (1999) studied response of different levels of fertilizers on growth and yield of hybrid Capsicum $c v$. Bharath and observed the $\mathrm{N}$ at $240 \mathrm{~kg} / \mathrm{ha}+\mathrm{P}$ at $180 \mathrm{~kg} / \mathrm{ha}$ produced the highest mean number of fruits per plant (7.51), $\mathrm{N}$ at $180 \mathrm{~kg} / \mathrm{ha}+\mathrm{P}$ at 180 $\mathrm{kg} / \mathrm{ha}$ produced the highest yield of 52.1, 64.3 and $80.6 \mathrm{q} / \mathrm{ha}$.
Benefit cost ratios were highest $(3.25,4.02$ and 4.67) with $\mathrm{N}$ at $180 \mathrm{~kg} / \mathrm{ha}+\mathrm{P}$ at 120 $\mathrm{kg} / \mathrm{ha}$.

Capsicum annuum var. grossum cv. California Wonder was sown at different densities (60x30, 60x45 and 60x60 cm spacing) and was supplied with $4 \mathrm{~N}$ rates $(0,50,100$ and $150 \mathrm{~kg} / \mathrm{ha})$ and $3 \mathrm{P}$ rates $(0,50$ and $100 \mathrm{~kg} / \mathrm{ha})$ at Coimbatore, Tamil Nadu, India. The results revealed that total chlorophyll content and harvest index were the highest when $150 \mathrm{~kg}$ $\mathrm{N} / \mathrm{ha}+100 \mathrm{~kg}$ P/ha was applied. NAR, RGR and CGR were not affected by $\mathrm{N}$ and $\mathrm{P}$ rates (Maya et al., 1999).

Revanappa et al., (1998) to study the effect of different nitrogen levels (150, 200 and 250 $\mathrm{kg} / \mathrm{ha}$ ) on the growth and yield of the Capsicum annum L cultivars during summer and kharif, season. It was observed that the Plant height $(56.07$ and $68.67 \mathrm{~cm}$ in summer and kharif, respectively) and spread (39.08 and $48.57 \mathrm{~cm}$ in summer and kharif, respectively). However, Capsicum annum L. cultivars recorded the highest yields (114.51 and $125.70 \mathrm{q} / \mathrm{ha}$ in summer and kharif, respectively). The highest $\mathrm{N}$ rate produced the maximum growth and yield.

Srinivasan et al., (1997) reported that $\mathrm{N}$ at 240 $\mathrm{kg} \mathrm{ha}^{-1}+\mathrm{P}$ at $180 \mathrm{~kg} \mathrm{ha}^{-1}$ produced the highest mean number of fruits per plant (7.51) in capsicum.

Maya et al., (1997) conducted a trial in Coimbatore to evaluate the effects fertilizers on the yield and growth of sweet pepper (Capsicum annuum var. grossum) cv. California Wonder and observed the fruit yield and plant growth generally increased as $\mathrm{N}$ and $\mathrm{P}$ application rates, the highest yield (12.13 $\mathrm{t} / \mathrm{ha}$ ) and with $\mathrm{N}$ and $\mathrm{P}$ application rates of 150 and $100 \mathrm{~kg} / \mathrm{ha}$, respectively. Manchanda et al., (1988) reported that Increasing rates of $\mathrm{N}$ increased plant height, the number of primary branches per plant, leaf area, number of fruits 
per plant, fruit length and breadth, and fruit yields. $\mathrm{N}$ at $160 \mathrm{~kg} / \mathrm{ha}$ gave the highest fruit yield (115.4 q/ha).

Prabhakar (1984) recorded higher TSS content with $60 \mathrm{~kg} \mathrm{P}_{2} 0_{5}$ and $50 \mathrm{~kg} \mathrm{~N} \mathrm{ha}^{-1}$ in capsicum.

Ramachandran and Subbiah (1981) conducted trials on Capsicum cv. MDU- 1, received $\mathrm{N}$ at $40,80,120$ or $160 \mathrm{~kg} / \mathrm{ha}$. The number of shoots and fruits/plant and the weight of 100 fruits generally increased with rising $\mathrm{N}$ rates. The highest yield/ha (2358.33 kg) was obtained from at $120 \mathrm{~kg} \mathrm{~N} / \mathrm{ha}$.

Dry matter content was found to increase at highest concentration of phosphorus (64 $\mathrm{kg}$ )/hectare and as well as at highest concentration of nitrogen $(100 \mathrm{~kg}) /$ hectare. Protein content was found to increase with increasing nitrogen doses and was also found to increase at maximum dose of nitrogen with increasing concentration of phosphorus.

Capsaicin and ascorbic acid content were found to be more at $\mathrm{P} \sim(64 \mathrm{~kg}) /$ hectare level at different doses of nitrogen. Maximum uptake of phosphorus and dry matter content was observed at nitrogen $(0 \mathrm{~kg}) /$ hectare with phosphorus $(64 \mathrm{~kg}) /$ hectare. Maximum protein, ascorbic acid and capsaicin contents were found at nitrogen $(100 \mathrm{~kg}) /$ hectare with phosphorus $(48 \mathrm{~kg}) /$ hectare. [Bajaj et al., (1979)]

After reviewing above research articles and abstracts it can be concluded that application of nutrients like nitrogen and phosphorusis well known to enhance the crop growth and development for optimum yield and to improve quality of produce. It is evident from literature, that nitrogen and phosphorus affect growth, yield and quality of fruits and vegetables. Proper management of fertilizers including ensuring the availability of essential nutrient components in proper doses is also necessary to attain considerable production and quality yield of capsicum.

\section{References}

Anonymous (2017). Horticulture statistics at a glance 2017.

Alhrout, Hussein Hussein, 2017. Response of growth and yield components of sweet pepper to two different kinds of fertilizers under green house conditions in Jordan. Journal of Agricultural Science; 9(10): 265272.

Arya, P. S. 1999. Vegetable breeding and seed production. Kalyani Publishers, Ranjinder Nagar, Ludhiana, India.

Bajaj, K. L., Kaur, Gurdeep, Singh, Jarnail, Brar, J. S. 1979. Effect of nitrogen and phosphorus levels on nutritive values of Sweet Peppers (Capsicum annum L.) fruits. Qualitas Plantarum 28(4): 287-292.

Buckman, H. O. and Brady, N. C. 1980. The nature and properties of soils. Eurasis Publishing House (P) Ltd. New Delhi110055. pp. 456-457.

Chaudhary, A. S. Sachan, S.K. Singh, R.L. 2007. Effect of spacing, nitrogen and phosphorus on growth and yield of capsicum hybrid. International Journal of Agricultural Sciences. 3(1): 12-14.

Diaz, L.T., Torres, Dorante, L. O., Zoghbi, A. de. and Rodriguez, L. de. 2001. Effect of four fertilization programmes on the foliar nutrients and yield of pimento (Capsicum annuum L.). Proceedings of the Inter American Society for Tropical Horticulture. 44: 5-12.

Dubey, Ashish Kumar, Singh,Devi, Rajput, Pranjal Singh, Yogesh Kumar, Verma, Ajay Kumar and Chandraker, Sandip Kumar 2017.Effect of NPK on plant growth, yield and quality of Capsicum(Capsicum annum L.) c.v. Swarna under shade net condition. Int.J.Curr.Microbiol.App.Sci (2017) 6(3): 1085-1091.

Faiza, A., Muhammad, I., Wadan, H.D. and Muzammil, S. 2002. Effect of different levels of nitrogen and plant spacing on the growth and yield of sweet pepper cv. Yellow Wonder. Sarhad Journal of Agriculture. 18 
(3): 275-279.

Gare, B. N., More, S. M., Jadhav, M. G. and Burli, A. V. 2001. Effect of spacing and fertilizer on yield of rainfed chilli in sub-montane zone of Maharashtra. Journal of Maharashtra Agricultural Universities. 2000 publ 25(3): 270-271.

Hossain, M. Z. 1990. Effect of nitrogen and phosphorus on growth, yield and nutrient content of rice. An M. Sc. thesis, Department of Soil Science, Bangladesh Agricultural University, Mymensingh, P: 17.

Islam, Md. Rizvi, Sultana, Tania, Haque,Md. Ahsanul, Hossain,Md. Ismail, Sabrin, Naima, And Islam, Rabiul (2018). Growth and yield of chilli influenced by nitrogen and phosphorus. IOSR Journal of Agriculture and Veterinary Science. 11(5): 54-68.

Jan, N. E., Khan, I. A., Ahmed, S., Shafiullah and Khan,R. 2006. Evaluation of optimum dose of fertilizer and plant spacing for sweet peppers cultivation in Northern Areas of Pakistan. Sarhad Journal of Agriculture. 22(4): 601-606.

Juroszek, P., \& Tsai, H. H. (2009). Yields of organically grown sweet pepper cultivars and lines during the hot-wet and cool-dry season in the tropics. Horticultural Technology, 19(2), 418-422.

Kacha, R.P., Sadhu, A.C., Tank, D.A. and Gediya, K. M.2008. Green fruit yield, quality and nutrient uptake by chillies (Capsicum annuum L.) as influenced by spacings, castor cake and nitrogen levels. Research on Crops. 9(2): 356-359.

Khan, M. S. I., Roy S. S., and Pall, K. K. 2010. Nitrogen and phosphorus efficiency on the growth and yield attributes of capsicum. Academic Journal of Plant Sciences 3: 7178.

Khan, Abid, Shah, SyedNoor Muhammad, Rab, Abdur, Muhammad Sajid, Kawsar Ali, Ahmed, Amjed and Faisal, Shah 2014.Influence of nitrogen and potassium levels on chillies (Capsicum annuum L.). Intl J Farm \& Alli Sci. Vol., 3 (3): 260-264, 2014.

Lodhi, Yugalkishor, Chakravorty, Snehasish, Prasad, BVG and Jena, Jagadish (2017). Effect of Nutrients and Mulching Application on Growth and Flowering Behavior of Bell
Pepper (Capsicum frutescence) in Red and Lateritic Belt of West Bengal. Trends in Biosciences, 2017, 10(23), 4763-4768.

Lodhi, Yugalkishor, Chakravorty, Snehasish, Prasad, BVG and Sangeeta (2019). Influence of nutrients and mulching on fruiting and fruit characteristics of bell pepper (Capsicum annum L.). The Pharma Innovation, 2019; 8(6): 791-794.

Lodhi, Yugalkishor, Chakravorty, Snehasish, Trivedi, Jitendra and Sangeeta (2019). Effect of different nutrients levels and mulches on fruit quality and chlorophyll content of bell pepper (Capsicum annum L.) Inter. J. of Fauna and Biological Studies, 2019; 6(4): 29-31.

Lodhi, Yugalkishor, Chakravorty, Snehasish, Prasad, BVG and Sangeeta (2019). Effect of nutrient levels and mulching materials on yield of bell pepper (Capsicum annum L.) under West Bengal condition. J. of Pharmacognosy and Phytochemistry, 2019; 8(3): 4250-4252.

Malik, A.A., Chattoo, M. A. Sheemar, G. and Rashid, R. 2011. Growth, yield and fruit quality of sweet pepper hybrid SH-SP-5 (Capsicum annuum L.) as affected by integration of inorganic fertilizers and organic manures (FYM). International Journal of Agricultural Technology. 7(4): 1037-1048.

Manchanda, A. K., Bhopal, S. and Singh, B. 1988. Effect of plant density on growth and fruit yield of bell pepper (Capsicum annuum L.) Indian Journal Agronomy. 33(4):445-447.

Maya, P., Natarajan, S. and Thamburaj, S. 1997. Effect of spacing, $\mathrm{N}$ and $\mathrm{P}$ on growth and yield of sweet pepper $c v$. California Wonder. South Indian Horticulture. 45(1/2): 16-18

Maya, P., Natarajan, S. and Thamburaj, S. 1999. Effect of plant density and nutrients on certain physiological parameters in sweet pepper. South Indian Horticulture. 47(1/6): 237-238.

Mebratu A, Dechassa N, Mulualem T, Weldetsadik K. (2014). Effect of Inorganic Fertilizers on Yield and Physical Quality Parameters of Hot Pepper (Capsicum annuum 1.) in South-Eastern Ethiopia. Journal of Plant and Pest Science. 1 (3): 138-145 
Mohanty, B. K., Hossain, M. M. and Nanda, S.K. 2001. Response of chilli cv. Utkal Rashmi to nitrogen, phosphorus and potash. Orissa Journal of Horticulture. 29(2): 51-53.

Muhammad, S., Muhammad. I., Noorul, A., Muhammad. A. and Ziaur, R. 2001. Effect of nitrogen and phosphorous on growth and yield of red chillies. Sarhad Journal of Agriculture. 17(4): 549-551.

Naz S, Anjum MA and Ahmad I. 2006. Growth of chilli (Capsicum annuum L.) F1 hybrid sky line-2 in response to different ages of transplants. J Res (Sci) 17: 91-95.

Qawasmi, W., Munir, J. M., Najim, H. and Remon, Q. 1999. Response of bell pepper grown inside plastic houses to nitrogen fertigation. J. Commun. Soil Sciences Plant Annals 30(17): 2499-2509.

Prabhakar, M., and Naik, L.B. 1984. Effect of supplemental irrigation and nitrogen fertilization on growth, yield, nitrogen uptake and water use of green chilli. Annals of Agricultural Research. 18(1): 34-39.

Ramachandran, S. and Subbiah, K. K. 1981. Studies on the effect of plant density and graded levels of nitrogen on yield and yield components of chillies (Capsicum annuum). South Indian Horticulture. 29(4): 178-181.

Ramakrishna, T. and Palled, Y. B. 2003. Effect of Plant Geometry and Fertilizer Levels Growth and Yield of Chilli. Karnataka journal Agricultural Science, 18(4): (892-895).

Revanappa, Nalawadi, U. G. and Madalageri, B. B.1998. Influence of nitrogen on branching, dry matter production and yield of green chilli. Karnataka Journal of Agricultural Sciences. 11(2): 458-461.

Roy, S.S., Khan, M.S.I. and Pall, K. K. 2011. Nitrogen and phosphorus efficiency on the fruit size and yield of capsicum. Journal of Experimental Sciences Volume. 2(1) 32-37.

Santos, B. M., Dusky, J. A., Stall, W. M., Bewick, T. A. and Shilling, D. G. 2004. Mechanisms of interference of smooth pigweed and common purslane on lettuce as influenced by phosphorus fertility. Weed Sci., 52(1): 78-82.

Sarma, U.J., Baruah, J. P., Suhrawardy, J., Narzary, B. D. and Chakravarty, M. 2004 Effect of various NPK levels on yield and capsaicin content in direct seeded chilli (Capsicum annuum). Indian Journal of Hill Farming. 17 (1/2): 15-18.

Safford, W.E. (1926). Our heritage from the American Indians. Annual Report Samithson Institute, pp 405-410.

Singegol, H.Y., Patil, H.B. and Patil, D.R. 2007. Growth and yield of green chilli (Capsium annuиm L.) cv. Pusa Jwala as influenced by nitrogen and phosphorus. Asian Journal of Horticulture. 2 (2): 184-187.

Singh, D. K., Jain, S. K. 2004. Interaction effect of nitrogen and phosphorus on yield and economics of chilli (Capsicum annuum L.), cv. Pant C-1. Scientific Horticulture. 9: 97100.

Srinivasan, K., Veeraragavathatham, D., Kanthaswamy, V. and Thiruvudainambi, S. (1997). Effect of nitrogen and phosphorous on the yield and economics of hybrid capsicum. Horticultural College and Research Institute, Tamil Nadu Agricultural University, Coimbatore - 641 003, India. South Indian Horticulture. 47 (1/6): 57-60.

Srinivasan, K., Veeraragavathatham, D., Kanthaswamy, V. and Thiruvudainambi, S. 1999. Effect of nitrogen and phosphorous on the yield and economics of hybrid capsicum. South Indian Horticulture. 47(1/6): 57-60.

Stroehlein JL and Oebker NF. 1979. Effects of nitrogen and phosphorus on yields and tissue analysis of chili peppers. J Am Soc Hortic Sci 114: 559-563.

Uddin, M. K., Khalequzzaman K. M. 2003. Yield and yield component of winter chilli (capsicum annum) as affected by different level of nitrogen and boron. Pakistan Journal Biological. Science 6(6) 605-609.

\section{How to cite this article:}

Yugalkishor Lodhi, Sangeeta, Snehasish Chakravorty and Prasad, B.V.G. 2019. Enhanced Effect of Nitrogen and Phosphorus on Growth and Yield of Capsicum: A Review. Int.J.Curr.Microbiol.App.Sci. 8(11): 2425-2433. doi: https://doi.org/10.20546/ijcmas.2019.811.280 